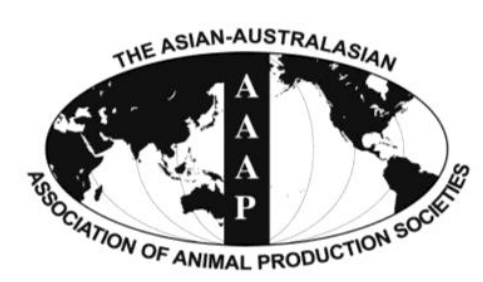

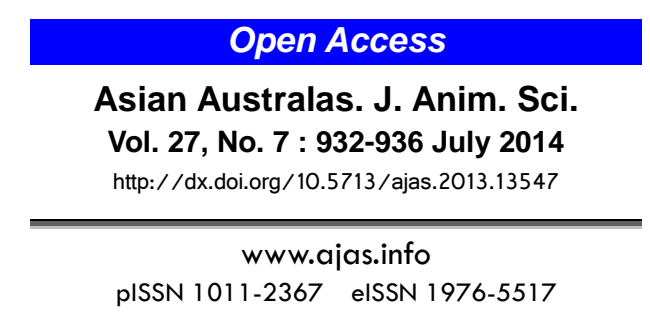

\title{
Reproductive Performance of Arabian and Thoroughbred Mares under Subtropical Conditions of Pakistan
}

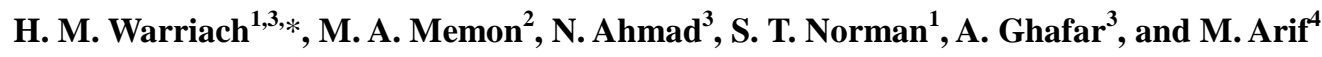 \\ ${ }^{1}$ School of Animal and Veterinary Sciences and Graham Centre for Agricultural Innovation, \\ Charles Sturt University, NSW, Australia
}

\begin{abstract}
Breeding records of 57 Arabian and 66 Thoroughbred mares were analysed to assess their reproductive performance under the subtropical conditions of Pakistan. The Arabian mares showed significantly higher conception rates $(p<0.05)$ in second mated oestrus and foal heat mated oestrus compared to Thoroughbred mares. However, conception rates for first lifetime mated oestrus were similar in both breeds of mares. Age at first mating $(1,301 \pm 40$ vs $1,500 \pm 32$ days $)$ was significantly ( $<<0.05)$ less in Arabian compared to Thoroughbred mares. Both breeds of mares showed significantly $(\mathrm{p}<0.05)$ higher frequencies of oestrous cycles and conception rates during the winter (October to March) compared to summer (June to August) months. Age of mares affected the conception rates, as mares at ages 3 to 7 and 8 to 12 years of ages had significantly higher conception rates $(p<0.05)$ than those $\geq 18$ years old in both breeds. This study demonstrates that i) reproductive performance in Arabians is better than Thoroughbred mares under the subtropical conditions of Pakistan, ii) mares remain cyclic throughout the year and iii) conception rates were higher in mares bred during winter compared to summer months. (Key Words: Mare, Reproductive Performance, Conception Rate, Pakistan)
\end{abstract}

\section{INTRODUCTION}

Limited information is available on the reproductive efficiency of Arabian and Thoroughbred mares (Demirci, 1987) from countries located in subtropical conditions. Retrospective studies on fertility across the world have revealed per cycle pregnancy rates ranging from $54 \%$ to $64 \%$ in Thoroughbred (Bruck et al., 1993) and $84 \%$ in Arabian mares (Benhajali et al., 2009). While there are a few reports of higher foaling rates, these perhaps are the result of better selection criteria and more intensive management of the mares (Morris and Allen, 2002). There are reports from Australia (Bruck et al., 1993), Sweden

\footnotetext{
* Corresponding Author: H. M. Warriach. Tel: +92-333-4315107, Fax: +92-42-99211461, E-mail: hassanwarriach71@yahoo.com

2 Department of Veterinary Clinical Sciences, College of Veterinary Medicine, Washington State University Pullman, USA.

${ }^{3}$ Department of Theriogenology, Faculty of Veterinary Sciences, University of Veterinary and Animal Sciences, Lahore, Pakistan.

${ }^{4}$ Remount Veterinary and Farms Corps, Pakistan.

Submitted Aug. 29, 2013; Revised Oct. 29, 2013; Accepted Nov. 28, 2013
}

(Hemberg et al., 2004), India (Sharma et al., 2009), and the UK (Sanderson and Allen, 1987) showing varied conception rates. Yet to our knowledge, no scientific studies have been reported on the reproductive performance of Arabian and Thoroughbred mares under subtropical conditions in Pakistan.

British cavalry imported Arabian and Thoroughbred breeds to improve the native breeds of the subcontinent which did not meet their standards back in eighteenth and nineteenth centuries.

Remount Veterinary and Farm Corps (RVFC) at Mona, Pakistan is one of the places established for horse breeding. Presently, it maintains more than 5,000 equines (horses, mules, donkeys) with accurate and reliable reproductive records. This stud started horse breeding in 1902, and it is enlisted as a full member of the World Arabian Horse Organisation.

The present study was designed to investigate various reproductive parameters of Arabian and Thoroughbred mares maintained at Mona. The aim was to investigate the reproductive performance of Arabian and Thoroughbred 
mares under subtropical conditions in Pakistan. Data generated from these studies will provide valuable information on the reproductive efficiency of mares in the subtropics and help to devise better strategies for equine breeding programs in a subtropical environment.

\section{MATERIALS AND METHODS}

\section{Database}

Breeding records of Arabian $(n=57)$ and Thoroughbred mares $(n=66)$ for ten consecutive (2000 to 2010) breeding seasons were reviewed at Mona, Pakistan (latitude $32^{\circ} 24 \mathrm{~N}$; longitude $73^{\circ} 06 \mathrm{E}$ ). Average temperature, humidity and rain fall during the period of data collection is shown in (Table 1). A survey form was developed and the data characterising reproductive performance was recorded and analysed. These data included mare's age, reproductive status, pregnancy status, twining, abortion and foaling outcome. Conception rate $(\mathrm{CR})$ is defined as the number of mares that are diagnosed pregnant between 30 to 45 days postovulation compared with the total number of mares bred. Seasonal (or cumulative) CR signifies the proportion of mares that conceive during the course of the breeding season compared to the number of mares bred or exposed to the stallion. To maintain the farm confidentiality, all mares were identified by numerical codes.

\section{Management}

Mares were fed a daily ration according to their reproductive status. This usually consisted Lucerne hay and paddock grass ad libitum plus approximately $4 \mathrm{~kg}$ of concentrate divided twice or thrice/d. All mares were regularly assessed for various reproductive diseases by speculum examination of the vaginal vault, endometrial culture and cytology. Mares having the history or evidence of reproductive disorders (repeat breeders, uterine infections, anatomical defects) have been excluded from the data of the current study. Oestrus was monitored daily by teasing with a stallion in the early morning. Two veterinarians examined mares by palpation per rectum and by ultrasonography to verify the ovarian follicular status and uterine oedema (Bergfelt and Adams, 2007). Mares in oestrus were mated by natural service using a stallion inhand with known fertility. The mares were bred again $48 \mathrm{~h}$ later. The same two veterinarians performed pregnancy detection by ultrasonography (Falco Vet 100; Pie Med; Holland) or by transrectal palpation at 30 days postbreeding.

\section{Statistical analysis}

Chi-squared analysis was used to determine if there was an overall effect of each variable on the outcome of interest (Kranzler and Moursund, 1999) and, if the effect was significant $(\mathrm{p}<0.05)$. Multiple comparisons were made and each comparison was considered significant only after the Bonferroni adjustment. Age at first mating between Arab and Thoroughbred mares were analysed using a paired t-test. $p<0.05$ was regarded as significant. For part of the analysis, mares were categorised into breed or age groups. Age categories were 3 to 7 years; 8 to 12 years; 13 to 17 years and 18 years or older.

\section{RESULTS}

Arabian mares showed significantly higher conception rates $(p<0.05)$ compared to Thoroughbred mares in the second mated oestrous cycle and foal heat mated oestrus Table 2. However, conception rates for the first lifetime mated oestrus were similar in both breeds of mares. Age at first mating ( $1,301 \pm 40$ vs $1,500 \pm 32$ days) was significantly $(\mathrm{p}<0.05)$ less in Arabian as compared to Thoroughbred mares. Various reproductive traits like twining, abortion, still born and foal sex ratio are presented in Table 3 . Both breeds of mares showed significantly $(p<0.05)$ higher

Table 1. Average means of temperature, humidity and rain fall during the period of survey at Mona equine breeding farm in Pakistan

\begin{tabular}{lcccccc}
\hline \multirow{2}{*}{ Months } & \multicolumn{2}{c}{ Temperature $\left({ }^{\circ} \mathrm{C}\right)$} & & \multicolumn{2}{c}{ Humidity $(\%)$} & \multirow{2}{*}{ Rain fall $(\mathrm{mm})$} \\
\cline { 2 - 3 } \cline { 5 - 6 } & \multicolumn{1}{c}{ Maximum } & Minimum & & Morning & Evening & \\
January & $18.27 \pm 3.64$ & $5.62 \pm 3.28$ & & $87.41 \pm 10.91$ & $52.00 \pm 17.12$ & $0.95 \pm 3.78$ \\
February & $22.74 \pm 4.45$ & $9.61 \pm 2.93$ & & $83.26 \pm 13.45$ & $56.91 \pm 18.79$ & $3.11 \pm 8.96$ \\
March & $28.25 \pm 4.34$ & $14.45 \pm 2.48$ & & $79.52 \pm 10.14$ & $51.61 \pm 13.76$ & $1.28 \pm 5.74$ \\
April & $35.06 \pm 4.21$ & $19.47 \pm 3.1$ & & $55.98 \pm 15.08$ & $33.69 \pm 15.02$ & $0.65 \pm 3.28$ \\
May & $38.69 \pm 3.54$ & $24.04 \pm 2.57$ & & $50.73 \pm 12.39$ & $32.06 \pm 9.52$ & $1.68 \pm 11.58$ \\
June & $38.69 \pm 3.99$ & $25.29 \pm 2.65$ & & $60.57 \pm 17.96$ & $45.36 \pm 18.17$ & $3.14 \pm 10.21$ \\
July & $35.41 \pm 3.31$ & $27.39 \pm 17.07$ & & $79.45 \pm 11.75$ & $65.58 \pm 10.97$ & $6.83 \pm 19.91$ \\
August & $34.23 \pm 3.73$ & $25.85 \pm 2.19$ & & $85.85 \pm 6.83$ & $68.80 \pm 10.77$ & $5.41 \pm 15.22$ \\
September & $34.19 \pm 2.32$ & $23.62 \pm 2.54$ & & $87.37 \pm 5.55$ & $62.41 \pm 11.03$ & $1.39 \pm 4.96$ \\
October & $32.26 \pm 2.36$ & $18.59 \pm 2.96$ & & $84.32 \pm 7.30$ & $55.27 \pm 9.74$ & $0.12 \pm 0.76$ \\
November & $25.48 \pm 2.70$ & $12.12 \pm 2.8$ & & $89.60 \pm 7.15$ & $63.57 \pm 11.37$ & $0.26 \pm 1.07$ \\
December & $20.40 \pm 2.37$ & $6.25 \pm 2.25$ & & $89.07 \pm 3.73$ & $56.29 \pm 16.43$ & $1.14 \pm 8.71$ \\
\hline
\end{tabular}


Table 2. Conception rate in first, second and foal heat mated mares under subtropical conditions of Pakistan

\begin{tabular}{|c|c|c|c|c|c|c|c|}
\hline \multirow[b]{2}{*}{ Breed } & \multicolumn{2}{|c|}{ First mated oestrus* } & \multicolumn{2}{|c|}{ Second mated oestrus** } & \multicolumn{2}{|c|}{ Foal heat mated oestrus } & \multirow[b]{2}{*}{$\begin{array}{c}\text { Conception rate } \\
(\%)\end{array}$} \\
\hline & No. of mares & $\begin{array}{c}\text { Conception } \\
\text { rate }(\%)\end{array}$ & No. of mares & $\begin{array}{l}\text { Conception } \\
\text { rate }(\%)\end{array}$ & No. of mares & No. of mating & \\
\hline Arabian & 57 & 75 & 53 & $45^{\mathrm{a}}$ & 67 & 242 & $52^{\mathrm{a}}$ \\
\hline Thoroughbred & 66 & 62 & 64 & $22^{\mathrm{b}}$ & 57 & 240 & $33^{\mathrm{b}}$ \\
\hline
\end{tabular}

Values in the same column with different superscripts are different $(\mathrm{p}<0.05)$.

* Conception rate at first lifetime breeding.

** Conception rate at second oestrus cycle breeding (includes mares consecutively breeding second lifetime).

Table 3. Various reproductive traits in mares under subtropical conditions of Pakistan

\begin{tabular}{lcccccc}
\hline Breed & No. of mares & $\begin{array}{c}\text { Age at } \\
\text { first mating }(\mathrm{d})\end{array}$ & $\begin{array}{c}\text { Twining } \\
\text { rate } \%^{*}\end{array}$ & $\begin{array}{c}\text { Abortion } \\
\text { rate } \%\end{array}$ & $\begin{array}{c}\text { Dead born } \\
\text { rate } \%\end{array}$ & $\begin{array}{c}\text { Foal sex ratio } \\
\text { Filly:colt }\end{array}$ \\
\hline Arabian & 57 & $1,301 \pm 40^{\mathrm{a}}$ & - & 3 & 3 & $54: 46$ \\
Thoroughbred & 64 & $1,500 \pm 32^{\mathrm{b}}$ & 3 & 8 & 7 & $49: 51$ \\
\hline
\end{tabular}

Values in the same column with different superscripts are different $(\mathrm{p}<0.05)$.

* Termination in abortion.

frequencies of oestrous cycles and conception rates during the winter (October to March) months Figure 1 and 2. Age of mares affected the conception rates, as mares at ages 3 to 7 and 8 to 12 years of ages had significantly higher conception rates $(\mathrm{p}<0.05)$ than those $\geq 18$ years old in both breeds Figure 3.

\section{DISCUSSION}

To the best of our knowledge, this is the first report on reproductive performance of Arabian and Thoroughbred mares under subtropical conditions of Pakistan. The present study demonstrates higher conception rates in Arabian (45\% and 52\%) compared to Thoroughbred (22\% and 33\%) mares bred during second mated oestrus and foal heat mated oestrus, respectively. The higher conception rate in Arabian mares may be due to a genetic trait of adaptability in warmer climates.

The first lifetime mated oestrus conception rates found in this study (75\% and 62\%) were comparable to $80 \%$ and 66\% reported by Demirci (1987) for Arabian and Thoroughbred mares (Hemberg et al., 2004), respectively. Therefore, it suggests that overall reproductive efficiency for both breeds did not differ in the present facility compared to other parts of the world. The aetiology of the CR discrepancy between Arabian and Thoroughbred mares may be multifactorial. In other species such as cattle, there are precedents where selective breeding for nonreproductive traits have lead to reduced fertility (Lucy, 2001). In Thoroughbred mares there have been many years of selective breeding for athletic ability, coupled with widespread use of reproductive technologies to assist subfertile mares to produce foals. The effect of these factors on fertility in Thoroughbred mares remains to be investigated.

In the present study, age of the mare is a major factor influencing conception rates in Arabian and Thoroughbred mares which is in agreement with several other studies

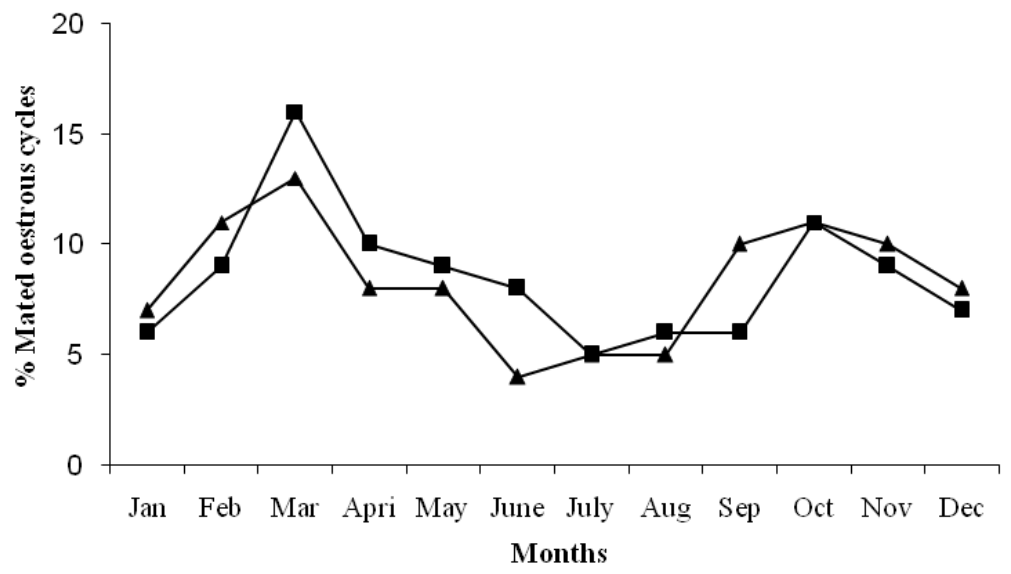

Figure 1. Distribution of mares mated during the whole year. Shown are the \% of mares mated oestrous cycles $(n=697)$ of Arabian $(\boldsymbol{\Delta})$ and $(n=1,110)$ of Thoroughbred ( $\mathbf{a})$ mares under subtropical conditions of Pakistan. 


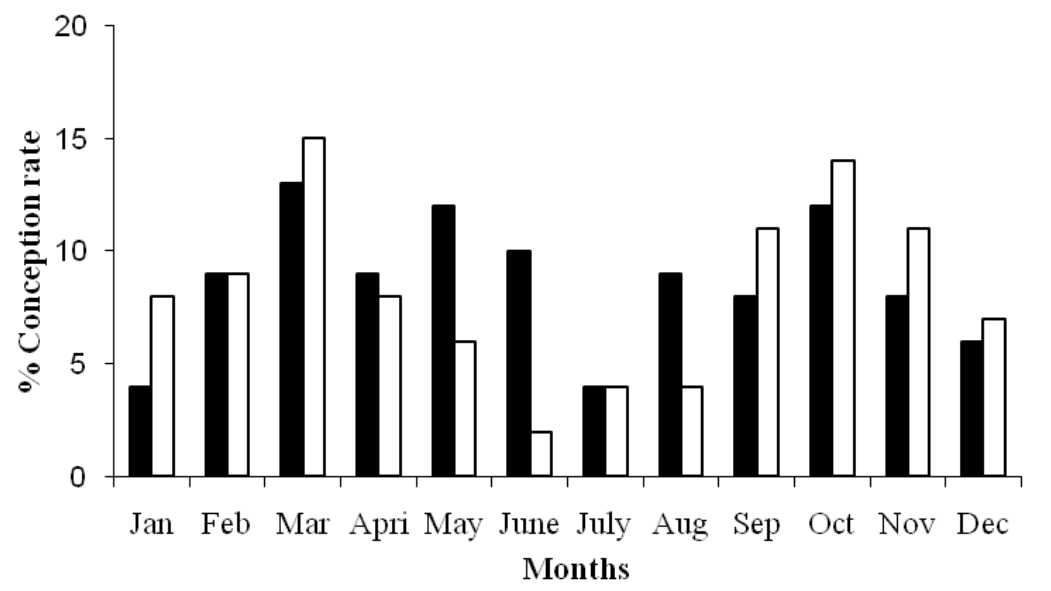

Figure 2. Observed pattern of conception rate during different months. Shown are the $\%$ of conception rates $(n=308)$ of Arabian $(\square)$ and $(n=336)$ of Thoroughbred ( $)$ mares under subtropical conditions in Pakistan.

(Samper et al., 2002; Davies Morel et al., 2005; Allen et al., 2007; Benhajali et al., 2009; Sharma et al., 2009). Most likely, the decline in fertility with age could be due to anatomic changes in perineal conformation and the physical barriers to uterine contamination leading to predisposition to pneumovagina, and urine pooling (Roberts, 1986); progressive degenerative changes in the endometrium; and susceptibility to endometrial infection that has been observed in older mares (Bracher et al., 1996). However, more studies are needed to determine if there is a definable point at which age should be considered when predicting foaling probabilities in mares within each endometrial category.

The present study clearly indicates that Arabian and Thoroughbred mares remain cyclic throughout the year in subtropical regions of Pakistan. In contrast to more temperate climates, frequencies of oestrous cycles and conception rates were significantly higher during the winter months. Most likely, higher frequencies of oestrous cycles and conception rates during winter compared to summer in this study could be due to a higher level of protein and energy in winter fodder compared to summer fodder (Khan et al., 2006). Furthermore, due to high temperature and humidity during the summer months, there is limited breeding of mares during June to August at the present facility.

\section{CONCLUSION}

This study demonstrates that under subtropical conditions of Pakistan i) reproductive performance in Arabians is better than Thoroughbred mares; ii) mares remain cyclic throughout the year; and iii) conception rates were higher in mares bred during winter compared to summer months.

\section{ACKNOWLEDGEMENTS}

The authors are grateful to Remount Veterinary and Farms Corps for cooperation and access to their records and

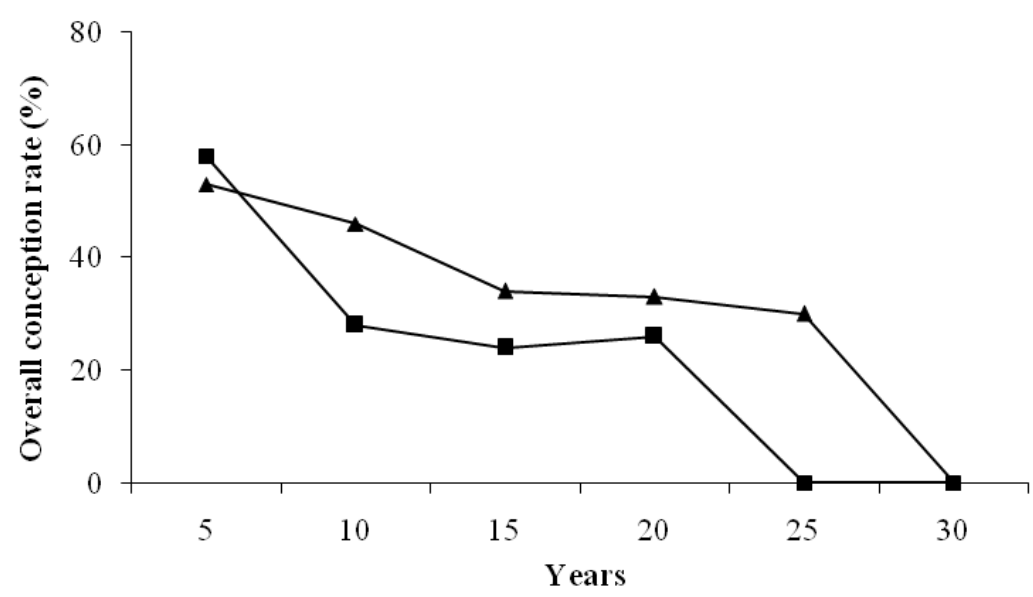

Figure 3. Overall conception rate (number of pregnant mares/number of mated mares) according to the mare's age. Shown are the $\%$ of conception rates of Arabian $(n=19)(\mathbf{\Delta})$ and Thoroughbred $(n=26)(\mathbf{\square})$ mares. 
David McGill (Charles Sturt University, Australia) for assistance in the statistical analysis.

\section{REFERENCES}

Allen, W. R., L. Brown, M. Wright, and S. Wilsher. 2007. Reproductive efficiency of Flatrace and National Hunt Thoroughbred mares and stallions in England. Equine Vet. J. 39: 438-445.

Benhajali, H., M-A. Richard-Yris, M. Ezzaouia, F. Charfi, and M. Hausberger. 2010. Factors influencing conception rates of Arab mares in Tunisia. Anim. Reprod. Sci. 117:106-110.

Bergfelt, D. R. and G. P. Adams. 2007. The normal female reproductive system. In: Current Therapy in Equine Reproduction (Ed. J. C. Samper, J. F. Pycock, and A. O. McKinnon). Saunders/Elsevier. Pp. 1-13.

Bracher, V., S. Mathias, and W. R. Allen. 1996. Influence of chronic degenerative endometritis (endometriosis) on placental development in the mare. Equine Vet. J. 28:180-188.

Bruck, I., G. A. Anderson, and J. H. Hyland. 1993. Reproductive performance of Thoroughbred mares on six commercial stud farms. Aust. Vet. J. 70:299-303.

Davies Morel, M. C. G., J. R. Newcombe, and J. C. Swindlehurst. 2005. The effect of age on multiple ovulation rates, multiple pregnancy rates and embryonic vesicles diameter in the mare. Theriogenology 63:2482-2493.

Demirci, E. 1987. Fertility in purebred Arab horses in Turkey. Anim. Reprod. Sci. 15:265-271.
Hemberg, E., N. Lundeheim, and S. Einarsson. 2004. Reproductive performance of Thoroughbred mares in Sweden. Reprod. Domest. Anim. 39:81-85.

Khan, S., A. Hussain, and M. S. Zahid. 2006. Status paper on fodder production in Pakistan. Fodder Research Programme, Crop Sciences Institute, National Agricultural Research Center, Islamabad, Pakistan.

Kranzler, G. and J. Moursund. 1999. Statistics for the Terrified, 2nd ed. Prentice Hall, Upper Saddle River, pp. 120-125.

Lucy, M. C. 2001. Reproductive loss in high-producing dairy cattle: Where will it end? J. Dairy Sci. 84:1277-1293.

Morris, L. H. A. and W. R. Allen. 2002. Reproductive efficiency of intensively managed Thoroughbred mares in Newmarket. Equine Vet. J. 34:51-60.

Roberts, S. J. 1986. Infertility in the mare. Veterinary Obstetrics and Genital diseases. (Theriogenology). 3rd ed. Published by the author, Woodstock. pp. 599-600.

Samper, J. C., M. Vidament, T. Katila, J. Newcombe, A. Estrada, and J. Sargeant. 2002. Analysis of some factors associated with pregnancy rates of frozen semen: a multi-centre study. Theriogenology 58:647-650.

Sanderson, M. W. and W. R. Allen. 1987. Reproductive efficiency of Thoroughbred mares in the United Kingdom. In: Proceedings of the 9th Bain Fallon Memorial Lectures, Ed: T. Huntington, AEVA, Sydney. pp. 31-41.

Sharma, S., G. S. Dhaliwal, and D. Dadarwal. 2010. Reproductive efficiency of Thoroughbred mares under Indian subtropical conditions: A retrospective survey over 7 years. Anim. Reprod. Sci. 117:241-248. 